Caries Res. 1981;15:I-VI

\title{
Contents, Vol. 15, 1981
}

\section{No.l Original Paper}

Binding of Salivary Aggregating Factors for Streptococcus mutans Concanavalin A and FucoseBinding

\section{Protein}

Mirth, D.B.; Miller, C.J.; Kingman, A.; Bowen, W.H

Factors Affecting the Adsorption of Salivary Acidic Proline-Rich Proteins to Hydroxyapatite Bennick, A.; Cannon, M.; Madapallimattam, G

Regulation of Lactic Acid Production by Leptotrichia buccalis

Brown, A.T.; Gross, M.L 21

The Source of Infection in the Intrafamilial Transfer of Streptococcus mutans

Rogers, A.H. (Adelaide) 26

Relationship between Fluoride Resistance of Streptococcus mutans 6715 and Medium pH

Schuster, G.S.; Whitford, G.M.; Lankford, M.T. 32

A Semi-Quantitative Determination of Streptococcus mutans Using Its Adherent Ability in a Selective Medium

Matsukubo, T; Ohta, K.; Maki, Y.; Takeuchi, M.; Takazoe, 1

Effect on Rat Caries of Endogenous and Exogenous Hydrogen Peroxide

Mühlemann, H.R.; Schmid, R.; Firestone, A.R 46

Influence of Carbohydrates on in vitro Lesion Production

Huang, C.T.; Little, M.F.; Johnson, R

Remineralization of Artificial Enamel Lesions in vitro. IV. Influence of Fluorides and

Diphosphonates on Short- and Long-Term Remineralization

Cate, J.M. ten; Jongebloed, W.L.; Arends, J 60

Distribution of Magnesium in Mature Human Enamel

Robinson, C; Weatherèll, J.A.; Hallsworth, A.S $\quad 70$

$\mathrm{Ca}$ and P Distribution in Sound, Demineralised and Remineralised Human Surface Enamel

Wöltgens, J.H.M.; Bervoets, T.J.M.; Witjes, F.; Houwink, B 78

Bone Fluoride Concentrations after 16 Years of Drinking Water Fluoridation

Hefti, A.; Marthaler, T.M : $\quad$; 85

Fluoride Deposition in Enamel from Monofluorophosphate Application

Grøn, P.; Caslavska, V 90

Fluoride Tablets and Salivary Fluoride Levels

McCall, D.; Stephen, K.W.; McNee, S.G 98

Effect of Fluoridated Citrus Beverage on Dental Caries and on Fluoride Concentration in the

Surface Enamel of Children's Teeth

Gedalia, I.; Galon, H.; Rennert, A.; Biderco, I.; Mohr, 1103

Relative Rates of Progress of Artificial Carious Lesions in Bovine, Ovine and Human Enamel

Featherstone, J.D.B.; Mellberg, J.R 109

Announcement 
28th ORCA Congress 1981, and changed instructions

115

No. 2

Original Paper

The Effect of Diagnostic Criteria on the Sensitivity of Dental Epidemiological Data

Howat, A.P.; Holloway, P.J.; Brandt, R.S 117

IV

Contents

Dental Caries and Fluorosis in Breast-Fed and Bottle-Fed Children

Walton, J.L.; Messer, L.B. .. • 124

Remineralization of Natural and Artificial Lesions in Human Dental Enamel in vitro. Effect of

Calcium Concentration of the Calcifying Fluid (with 1 color plate)

Silverstone, L.M.; Wefel, J.S.; Zimmerman, B.F.; Clarkson, B.H.; Featherstone, M.J 138

Redistribution of Enamel Fluoride during White Spot Lesion Formation: an in vitro Study on Human Dental Enamel

Clarkson, B.H.; Wefel, J.S.; Silverstone, L.M 158

Oral Starch Degradation and Its Influence on Acid Production in Human Dental Plaque

Mörmann, J.E.; Mühlemann, H.R 166

Short Communication

Effect of Fluoridation on Lesion Depth and Microhardness Indentations of Artificial White Spot

Lesions

Arends, J.; Schuthof, J 176

Abstracts

Abstracts of Papers Presented at the 27th ORCA Congress, July 17-19,1980, Marburg, FRG

179

No. 3

Original Paper

Pharmacokinetics of Fluoride Gels in Children and Adults

Ekstrand, J.; Koch, G.; Lindgren, L.E.; Petersson, L.G 213

Physicochemical Requirements for Rapid Remineralization of Early Carious Lesions

Featherstone, J.D.B.; Rodgers, B.E.; Smith, M.W 221

Cariostatic Effect of Daily Use of a Fluoride-Containing Lozenge Compared to Fortnightly

Rinses with $0.2 \%$ Sodium Fluoride

Poulsen, S.; Gadegaard, E.; Mortensen, B 236

Dissolution of Hydroxyapatites Treated with Salivary Glycoproteins and Fluoride

Voegel, J.C.; Belcourt, A.; Gillmeth, S 243

Effect of Fluoride Varnishes and Nuva-Seal Resin Treatment on the Formation of Artificial

Carious Lesions

Dérand, T; Petersson, L.G 250

Effects on Dental Caries Incidence of Frequent Ingestion of Small Amounts of Sugars and

Stannous EDTA in Chewing Gum

Glass, R.L 256

Fermentation of L-Sorbose by Microorganisms of the Human Dental Plaque

Lohmann, D.; Gehring, F.; Karle, E.J 263

Erratum 272

No. 4

Original Paper 
A Study on Accumulation and Release of Loosely Bound Fluoride on Enamel Joost Larsen, M.; Lambrou, D.; Fejerskov, O.; Tachos, B 273

An Electron Microscope Study of Modifications to Defect Regions in Dental Enamel and Synthetic Apatites

Featherstone, J.D.B.; Nelson, D.G.A.; McLean, J.D 278

$\mathrm{V}$

Contents

Caries-Preventive Effects of Polycarboxylate Cement Containing $\mathrm{Na}^{\wedge} \mathrm{PC}^{1} / 8 \mathrm{~F}$ Sealed on

Occlusal Surfaces in Newly Erupted Permanent Molars

Sobue, S.; Okamoto, M.; Moriwaki, Y . 289

Effect of Using Different Strontium Salts on Dental Caries in the Rat

Curzon, M.E.J.; Spector, P.C 296

Cariogenicity of Invert Sugar in Long-Term Rat Experiments

Birkhed, D.; Topitsoglou, V.; Edwardsson, S.; Frostell, G 302

Caries Prevalence in Norwegian Recruits 5-7 Years after Discontinuation of Supervised

Fluoride Toothbrushing Programmes

Haugejorden, O.; Rise, J 308

Pit, Fissure and Smooth Surface Caries of First and Second Permanent Molars in Urban

Nigerians

Akpata, E.S 318

Distribution of Caries in Different Tooth Surfaces in 7-Year-Old Children

Bimstein, E.; Eidelman, E.; Klein, H.; Chosack, A 324

A Comparison of the Sensitivity of Caries Diagnostic Criteria

Howat, A.P 331

Short Communication

Topical Effects of a Quaternary Ammonium Compound on Caries Incidence and Bacterial

Agglomerate

Formation in the Rat

Firestone, A.R.; Schmid, R.; Mühlemann, H.R

338

No. 5

Original Paper

The Effect of Fluoride in Saliva on Remineralization of Dental Enamel in Humans

Lambrou, D.; Joost Larsen, M.; Fejerskov, O.; Tachos, B 341

The Histopathology of Enamel Caries in Fluorosed Deciduous Teeth

Kidd, E.A.M.; Thylstrup, A.; Fejerskov, 0346

Phosphate Diffusion in Whole Bovine Enamel at pH 7. II. Temperature, Time and

Concentration Dependency

Rooij, J.F. de; Arends, J 353

Diffusion of Monofluorophosphate in Whole Bovine Enamel at $\mathrm{pH} 7$

Rooij, J.F. de; Arends, J.; Kolar, Z 363

Apatitic Fluoride Increase in Enamel from a Topical Treatment Involving Intermediate CaHP < $3 / 4$

2H2O Formation, an in vivo Study

Chow, L.C.; Guo, M.K.; Hsieh, C.C.; Hong, Y.C 369

Effect of Acetic, Lactic and other Organic Acids on the Formation of Artificial Carious Lesions

Featherstone, J.D.B.; Rodgers, B.E 377 
Influence of Anatomical Site on Fluoride Levels in Rat Molars

Weatherell, J.A.; Robinson, C; Best, J.S 386

A Chemical and Histological Study of Artificial Caries in Human Dental Enamel in vitro

Ingram, G.S.; Silverstone, L.M 393

Fluoride in Gingival Crevicular Fluid and a New Method for Evaporative Water Loss Correction

Whitford, G.M.; Pashley, D.H.; Pearson, D.E 399

Total and Ionic Fluoride in Milk

Duff, E.J 406

A Survey of the Flora of Dental Plaque in Caries-Free People in New Zealand

Gallagher, I.H.C.; Fussell, S.J.; Hancock, E.M 409

VI Contents

Dental Caries and Streptococcus mutatis Prevalence in Cancer Patiens with Irradiation-Induced

Xerostomia: 1-13 Years after Radiotherapy

Keene, H.J.; Daly, T.; Brown, L.R.; Dreizen, S.; Drane, J.B.; Horton, I.M.; Handler, S.F.;

Perkins, D.H 416

Microbial Studies on Plaque from Carious and Caries-Free Proximal Tooth Surfaces in

a Population with High Caries Experience

Mikkelsen, L.; Børglum Jensen, S.; Jakobsen, J 428

Characterization of Dextran Glucosidase (1,6- $\alpha$-D-Glucan Glucohydrolase) of Streptococcus

mitis

Under, L.; Sund, M.-L 436

Secular Changes in Caries Prevalence in Two Massachusetts Towns

Glass, R.L 445

Short Communication

The Production of Artificial Caries-Like Lesions in Shark Enameloid in vitro

Clement, J.G.; Langdon, D.J.; Thistleton, A 451

No. 6

Original Paper

Fluoride Deposition in Enamel from Application of Sodium, Potassium or Ammonium Fluoride

Gron, P.; Caslavska, V 459

Effect of NaF, TiF4 and APF Solutions on Root Surfaces in vitro, with Special Reference to Uptake of $\mathrm{F}$

Hals, E.; Tveit, A.B.; Tötdal, B.; Isrenn, R 468

Solubility Behavior of COj Apaties in Relation to Crystallinity

Okazaki, M.; Moriwaki, Y.; Aoba, T; Doi, Y.; Takahashi, J. 477

Combined Effect of Iodine and Sodium Fluoride on Dental Caries in Rats and on Viability

of Streptococcus mutatis in vitro

Caufield, P.W 484

Glucose Incorporation by Human Dental Plaque Bacteria

Roberts, K.R.; Linder, L.; Sund, M.-L 492

Kinetics of Hydroxyapatite Dissolution during Incubation with Sucrose and Streptococcus mutatis

and Its Application to Cariogenetic Testing

Reynolds, E.C.; Riley, P.F. 501

Short Communications

Reversal of Fissure Caries in the Albino Rat by Sweetening Agents 
Leach, S.A.; Green, R.M 508

Effects on Caries in Rats of Calcium Glycerophosphate and Sodium Fluoride Administered Separately and Together

Edgar, W.M.; Bowen, W.H.; Amsbaugh, S.; Monell-Torrens, A 511

Effect of Invert Sugar on Accumulation of Streptococcus mutatis E49 on the Teeth of Rats

Okuda, K.; Frostell, G.

Announcements

Acknowledgements

Author Index

Subject Index 